\title{
SOME INVESTIGATIONS PERFORMED FOR THE BRIDGE OVER JIU AT ANINOASA
}

Ionuţ Radu Răcănel, Assoc.Prof.PhD.eng., Technical University of Civil Engineering Bucharest, The Faculty of Railways, Roads and Bridges, e-mail: ionut@cfdp.utcb.ro

Marian Daraban, Assistant PhD.eng., Technical University of Civil Engineering Bucharest, The Faculty of Railways, Roads and Bridges, e-mail: marian.daraban@yahoo.com

Răzvan Stănescu, Assistant $\mathrm{PhD}$ Student, Technical University of Civil Engineering Bucharest, The Faculty of Railways, Roads and Bridges, e-mail: razvan@cfdp.utcb.ro

\section{Abstract}

The carrying structure of the bridge over the Jiu River at Aninoasa consists in two parallel concrete arches with variable height of the cross section, sustaining a concrete deck through vertical concrete hangers. In the time period passed since the bridge was erected, some structural elements shown damages. In order to establish the technical state of the bridge, a technical appraisement was performed and according to this, the most exposed elements to the risk of failure are the hangers.

The purpose of this paper is to present briefly both, the method used to test the actual bridge carrying capacity in situ and the finite element model developed for the static and dynamic analysis of the structure.

In order to estimate the state of the structural elements, two ways were followed. In the first stage, a test project was carried out and in the second stage, a complete 3D finite element model was developed to analyze the bridge structure.

The test project has foreseen the loading of the bridge by heavy unloaded trucks, disposed in some positions on the deck and the measurements of the deck and arches displacements. The positions of the trucks were established in order to obtain the maximum values both for arches transverse displacements and vertical displacements of the deck. Using electro-resistive transducers the hangers elongations and strains values on their cross section were also measured. These measured values were compared with those obtained from the numerical calculations performed by using the complete finite element model. By means of the finite element model, also the response of the structure following the dynamic action of vehicles was investigated.

Keywords: bridge, cracks, hangers, deck, grillage, reinforcing bars 


\section{DESCRIPTION OF THE STRUCTURE}

The analyzed bridge structure is placed on the national road 66A Livezeni-Câmpu lui Neag, starts at $\mathrm{km} 2+178$ and crosses the Jiu River near Aninoasa. The bridge was finished in 1968 and it was designed for Class E of vehicles according to Romania norm.

The bridge superstructure consists in two parallel reinforced part tied concrete arches which are sustaining, through concrete hangers, a deck grillage including three longitudinal girders with cantilever for footways and prestressed concrete cross girders, disposed in the same sections as the hangers (Figura 1). As static system, the deck wad designed in "Gerber system", the central part of the deck between the first and the last hanger being sustained by the lateral parts, which are supported at their ends by the abutments. Above the deck grillage an $18 \mathrm{~cm}$ thick reinforced concrete slab was poured. The arches have a span of $70.00 \mathrm{~m}$ and a height of $14.30 \mathrm{~m}$ with respect to the line of arches springing, the distance between the axes of longitudinal girders is $3.95 \mathrm{~m}$ and the cross girders are placed at $5.40 \mathrm{~m}$ along the bridge deck. The total length of the bridge is about $81.00 \mathrm{~m}$. The deck is $11.20 \mathrm{~m}$ wide and includes the roadway with two lanes $7.80 / 2 \mathrm{~m}$ each, two footways of $1.50 \mathrm{~m}$ each and each side $20 \mathrm{~cm}$ representing the edge of the deck.

The bridge substructure consists in two massive abutments made of reinforced concrete which are resting on shallow foundations. Two quart of cones erected with dry walls made of free stone ensures the connection with the embankments at each end of the bridge.

Following a technical appraisement finalized in 2005 by "APECC" from Timişoara, many damages of the carrying structure of the bridge, but also of the roadway layers and of the bridge equipments (bearing devices, outflows, handrails, guiding guardrails) were observed. From all these damages, the most severe and which can affect the bridge safety, are the cracks observed at cross girders near to the Gerber snouts, but also at eleven hangers, seven on the right side and four on the left side of the bridge. At some hangers, the concrete which protects the reinforcing bars is seriously damaged, the cracks are vertical, their opening reaches $30 \mathrm{~mm}$ and they are developed on $25-100 \%$ from the length (Figura 2). 
ROMANIAN JOURNAL

OF TRANSPORT INFRASTRUCTURE

Ionuţ Radu Răcănel, Marian Daraban, Răzvan Stănescu,

Some investigations performed for the bridge over Jiu at Aninoasa
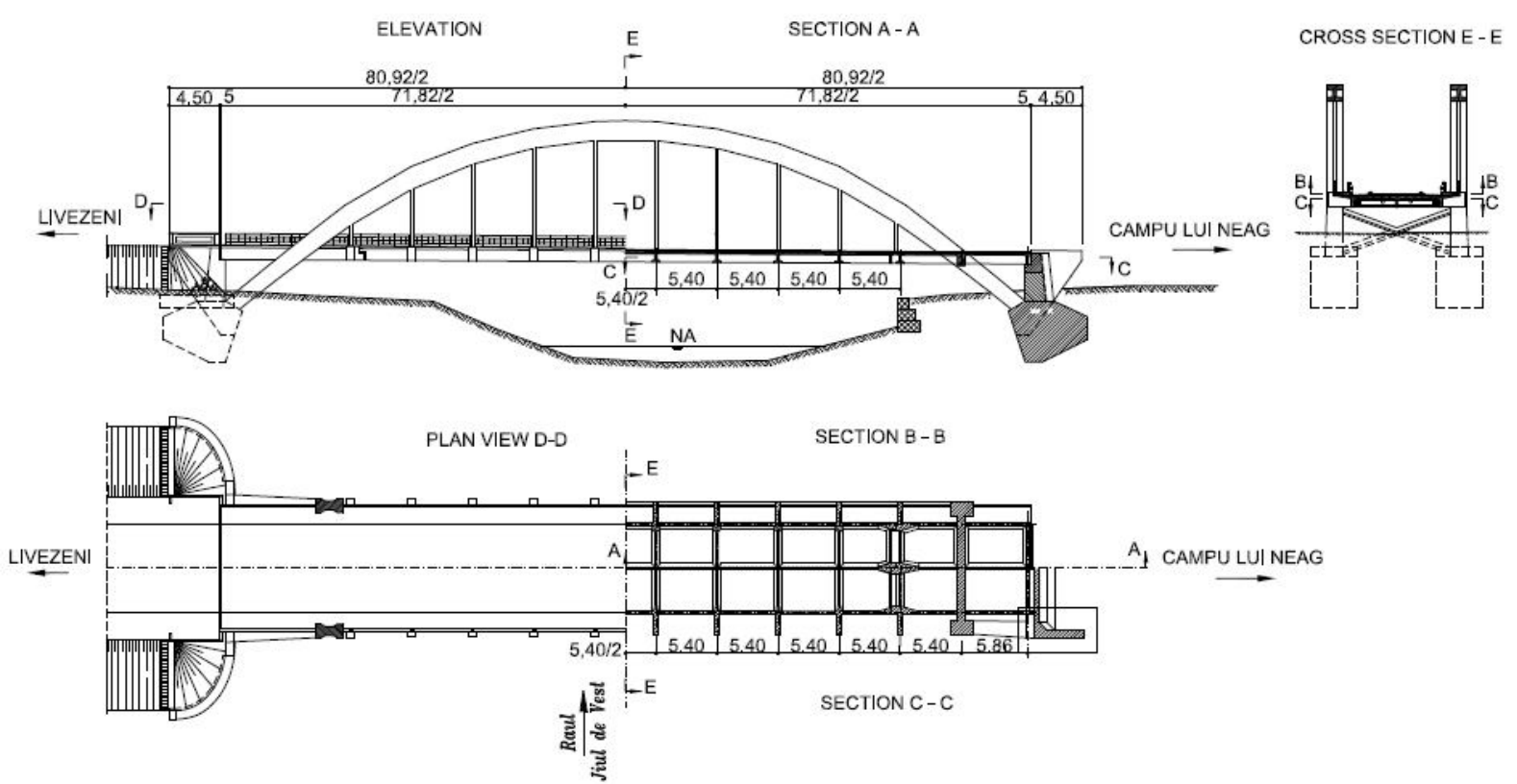

Figure 1. The bridge crossing Jiul de Vest River at Aninoasa
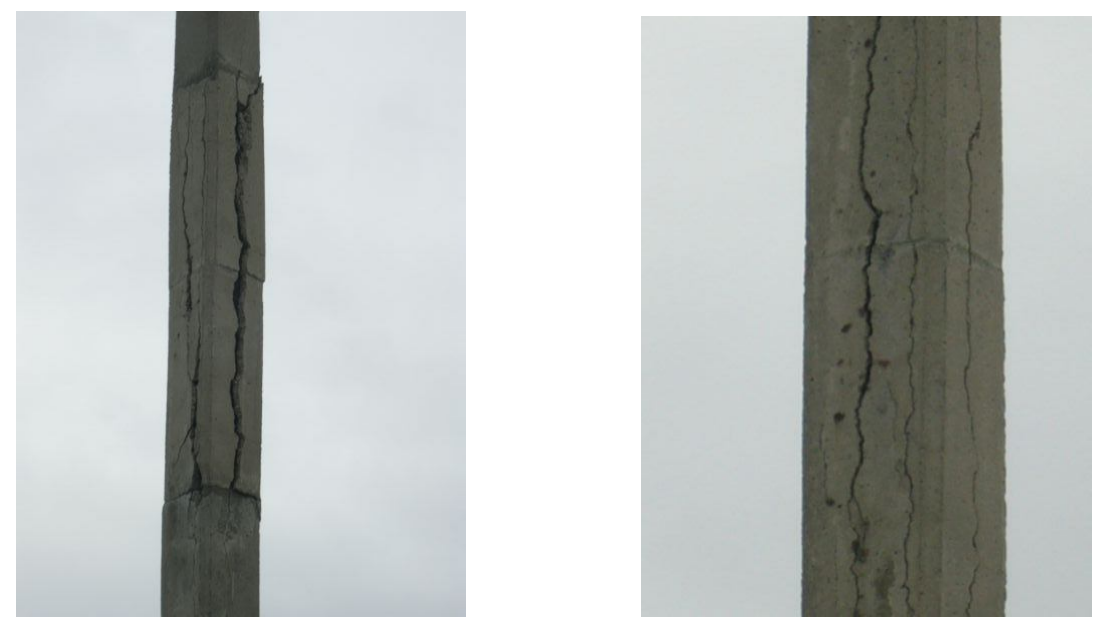

Figure 2. Cracks at some of the bridge concrete hangers

For this reasons, it was necessary to perform new analyses of the bridge structure, in order to find out the causes of these problems and to establish the measures and technology for the bridge strengthening. The analyses have included both numerical calculation and "in situ" tests with real trucks of the bridge structure. The numerical calculations were carried out at the "Bridges" 
ROMANIAN JOURNAL

\section{OF TRANSPORT INFRASTRUCTURE}

and "Computation of Structures" Departments of S.C. I.P.T.A.N.A. S.A. and the tests were performed by S.C. INCERTRANS S.A., being supervised by Dir. Iordănescu Constantin, Counselor Ing. Voicu Ion (S.C. I.P.T.A.N.A. S.A.) and Dir. Gheorghe Costel (S.C. INCERTRANS S.A.).

\section{2. "IN SITU” TESTS OF THE BRIDGE STRUCTURE}

For establishing both the stress state in the concrete hangers and also the displacements of some parts of the structure, a test project was realized. According to the project, the bridge was loaded with a special convoy in some critical sections, which were established in order to obtain maximum values of the stresses in hangers and vertical and horizontal displacements for arches. The convoy was composed from four unloaded trucks, their weight being 23 tons each. The loading positions can be observed in figure 3 .

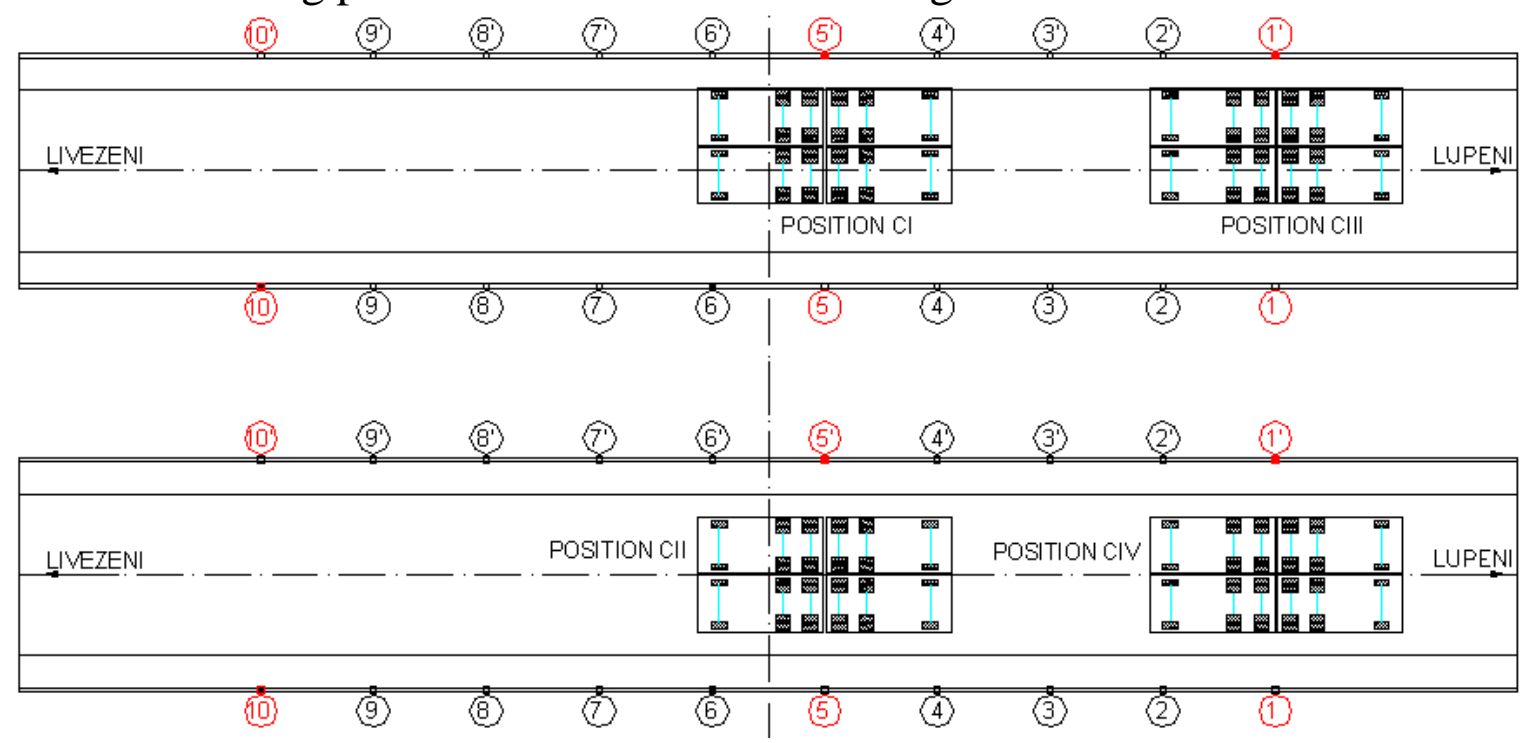

Figure 3. Test loading positions on the bridge deck, in plan view

For strains measurements, on four hangers - 1',5',6 and 10 (Figura 3) electro-resistive transducers type H350 (Huggenberger measurement points) were applied (Figura 4). The vertical displacements of arches and bridge deck were measured through high precision levelling using a Koni 007 level device and levelling marks placed in some sections aligned with the hangers (1-1';55';10-10'). 

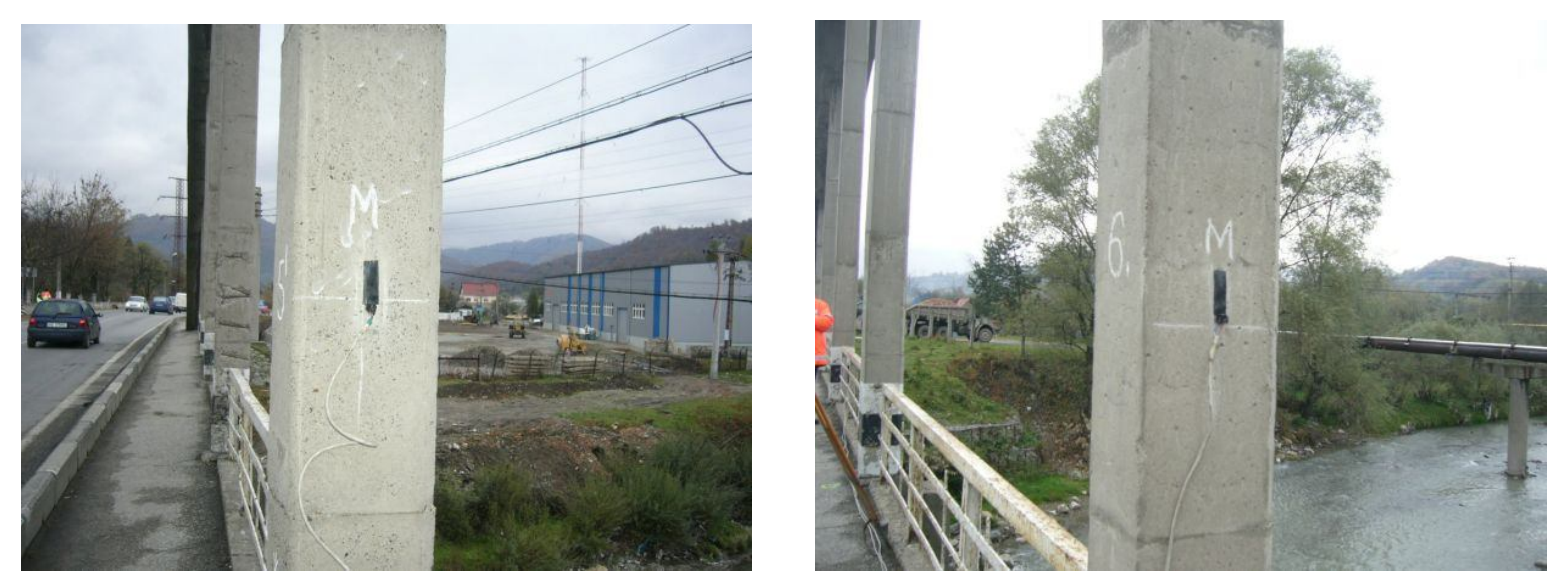

Figure 4. Electro-resistive transducers placed on the concrete hangers

Considering the measured values of strains, the corresponding the values of axial forces in the hangers were computed and together with the measured displacements of arches were compared with those obtained from finite element analyses.

\section{FINITE ELEMENT MODELS}

Because of the special geometry and complexity of the bridge, the analyses were performed using the finite element method. The 3D finite element model of the bridge (Figura 5) was realized so that it respects the static scheme of the structure, but also its behaviour under external loads.
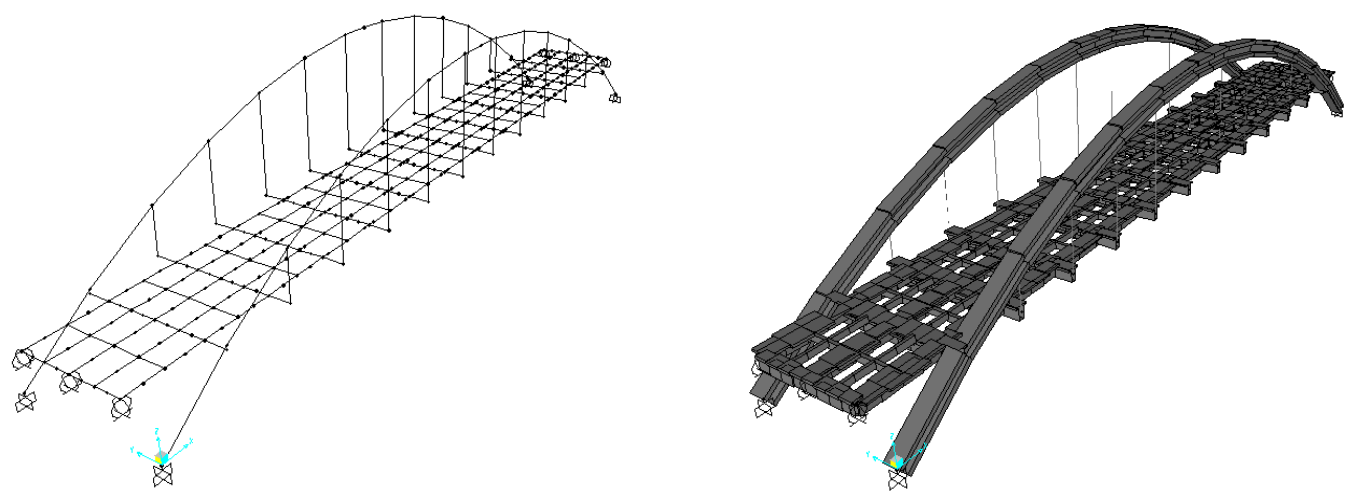

Figure 5. 3D finite element model of the bridge 
The bridge deck was modeled as a grillage using two nodes straight frame elements having activated all six degrees of freedom (three translations and three rotations). In longitudinal direction, the grillage elements were the three main girders which characteristics were estimated considering the effective width concept according to the Romanian norm STAS 10111/2-87, but also two supplementary beams for the remaining portion of the concrete slab, uncovered by the effective width. In transverse direction, in order to obtain an accurate distribution of the loads between the deck elements, the connection between the longitudinal elements was ensured by the cross girders considering their effective width, but also by transverse strips which are in fact appropriate portions of the concrete slab. The bending and torsion characteristics of these transverse strips were established in order to respect as much as possible the real behavior of the structure. The finite elements were disposed in the centroid of the concrete girders, the eccentricity between the centroid of the girders, concrete slab and cross girders being not accounted for, because it was assumed that its value will not affect in a significant manner the distribution of stresses.

For the arches were used the same type of finite elements as for the grillage, but considering for the element non-prismatic cross sections, whose properties can vary along the length. The variation of the bending stiffness was considered cubic and the axial, shear and torsional was assumed as linear over the element length.

The hangers were modeled also using straight frame elements with two nodes, but at their end, appropriate frame releases for free rotation were used, in order to obtain in elements only axial forces. The hangers cross section area was considered equal to the area of the reinforcement used for the hangers, the concrete cover of the reinforcement being not taken into account, because of the presence of cracks. For the connection between hangers and arches on one hand and between the hangers and the bridge deck on the other hand, appropriate constraints were used in order to respect the degree of freedoms produced by the real connections of the structural elements.

Because the substructure of the bridge consists in two massive abutments only, in the finite element model, appropriate restraints were considered for arches and longitudinal girders.

The behavior of both materials, steel for hangers cross section and concrete for other structural elements of the bridge, was considered linear elastic.

On this structural model static and dynamic analyses were performed, considering the effect of loading given by the test trucks. Following those analyses, the displacements of the structure in some critical points together with the stresses value in the structural elements were obtained. 
ROMANIAN JOURNAL

\section{OF TRANSPORT INFRASTRUCTURE}

The dynamic response of the bridge under the action of live loads, here an A30 vehicle, was established through dynamic linear time history analyses, using a direct integration method for the equations of motions, on a specified time domain. The linear character of the response was assumed because, for usual values of the speed of vehicles, the structure not exhibit large displacements and the behavior of the material still remain in linear elastic domain. The major advantage of the use of the methods based on the direct integration algorithms with respect to the modal analyses, is that they do not require the previously establishing of the eigenvalues and eigenforms of the structure, which lead to a significant reduction of the time spent for the numerical calculations.

\section{RESULTS AND CONCLUSIONS}

Following the loading of the bridge with test trucks in the positions presented in figure 3, the vertical displacement of the bridge deck were measured. It were considered 3 measurement points for each imaginary line connecting the end of hangers 1-1' and 5-5' and only two measurement points for the imaginary line which is connecting the end of hangers 10-10'. These points were, each side of the deck, the end of cross girders where their connection with the hangers is made and also the point on the longitudinal axis of the deck, at the intersection with the imaginary line which connects the hanger ends. In Table 1 is presented a comparison between the values of vertical displacements obtained from "in situ" tests and those resulted following the numerical analyses.

Table 1. Vertical displacements of the bridge deck

\begin{tabular}{|c|c|c|c|c|c|c|c|c|}
\hline \multirow{3}{*}{$\begin{array}{c}\text { Point } \\
\text { number }\end{array}$} & \multicolumn{2}{|c|}{ Position CI } & \multicolumn{2}{|c|}{ Position CII } & \multicolumn{2}{|c|}{ Position CIII } & \multicolumn{2}{|c|}{ Position CIV } \\
\hline & Measured & Computed & Measured & Computed & Measured & Computed & Measured & Computed \\
\hline & $(\mathbf{m m})$ & $(\mathbf{m m})$ & $(\mathbf{m m})$ & $(\mathbf{m m})$ & $(\mathbf{m m})$ & $(\mathbf{m m})$ & $(\mathbf{m m})$ & $(\mathbf{m m})$ \\
\hline $\mathbf{R}_{\mathrm{fAM}}$ & 0.00 & 0.00 & 0.00 & 0.00 & 0.00 & 0.00 & 0.00 & 0.00 \\
\hline 1' & -1.54 & -4.60 & -2.27 & -4.60 & 13.38 & 9.90 & 10.48 & 12.90 \\
\hline 1ax & -1.62 & -4.40 & -2.22 & -4.60 & $* * * * *$ & 13.50 & 13.68 & 14.00 \\
\hline 1 & -0.80 & -4.00 & -1.67 & -4.60 & 9.17 & 8.20 & 9.73 & 9.30 \\
\hline $5^{\prime}$ & 10.17 & 10.90 & 9.92 & 8.40 & 0.43 & 0.60 & 0.58 & 0.90 \\
\hline 5-6ax & $* * * * *$ & 14.00 & 14.16 & 14.20 & 0.93 & 0.70 & 1.19 & 0.90 \\
\hline 5 & 7.40 & 6.30 & 8.12 & 8.40 & 0.99 & 0.80 & 0.50 & 0.90 \\
\hline $10^{\prime}$ & -4.38 & -4.60 & -3.60 & -4.10 & -3.98 & -5.20 & -4.31 & -5.40 \\
\hline 10 & -3.28 & -4.10 & -3.30 & -4.10 & -3.67 & -5.10 & -3.90 & -5.40 \\
\hline
\end{tabular}


Values marked through "*****" in table 1 were not correct measured and for this reason were not taken into account for the comparison. From the table above, it can be observed a good accordance, especially for the maximum values, between the measured and computed displacements. The explanation for some bigger differences which appear for some positions of vehicles and measuring points can be explained through the fact that in the finite element model, the damages of the concrete existing for the real structural elements, could not be considered. These damages have a significant influence on the bending, shear and axial stiffness of the elements and for this reason the distribution of the loads between the bridge components could be affected.

In Table 2 are given, for each position of the test convoys, the measured values of the strains in the hangers where electro-resistive transducers are placed (see Chapter 2).

Table 2. Values of the measured strains

\begin{tabular}{|c|c|c|c|c|}
\hline $\begin{array}{c}\text { Point } \\
\text { number }\end{array}$ & $\begin{array}{c}\text { Position } \\
\text { CI } \\
(\boldsymbol{\mu \mathbf { m }})\end{array}$ & $\begin{array}{c}\text { Position } \\
\text { CII } \\
(\boldsymbol{\mu \mathbf { m }})\end{array}$ & $\begin{array}{c}\text { Position } \\
\text { CIII } \\
(\boldsymbol{\mu} \mathbf{m})\end{array}$ & $\begin{array}{c}\text { Position } \\
\text { CIV } \\
(\boldsymbol{\mu \mathbf { m } )})\end{array}$ \\
\hline $\mathbf{1}$ & -35 & -25 & 80 & 60 \\
\hline $\mathbf{5}$ & 30 & 20 & 25 & 20 \\
\hline $\mathbf{6}$ & 10 & 20 & -25 & -30 \\
\hline $\mathbf{1 0}$ & -40 & -25 & -10 & -10 \\
\hline
\end{tabular}

From table 2 it can be seen that in some hangers, for particular positions of vehicles on the deck, it is possible that some hangers are in tension, but considering also the self weight of the structure which has a high value, it is obvious that the hangers are compressed.

Following the time-history analyses performed on the finite element model, its has been established the dynamic response of the bridge when it is crossed by an A30 vehicle, acting on the bridge same side as the hangers 10 and 6 , at certain speeds $(30 \mathrm{~km} / \mathrm{h}, 80 \mathrm{~km} / \mathrm{h}$ and $120 \mathrm{~km} / \mathrm{h})$. In figures 6 is presented the evolution of axial force in hanger 10 during the vehicle action and in figures 7 the evolution of vertical displacement at the bottom of the same hanger respectively. 
ROMANIAN JOURNAL

OF TRANSPORT INFRASTRUCTURE

Ionuţ Radu Răcănel, Marian Daraban, Răzvan Stănescu,

Some investigations performed for the bridge over Jiu at Aninoasa

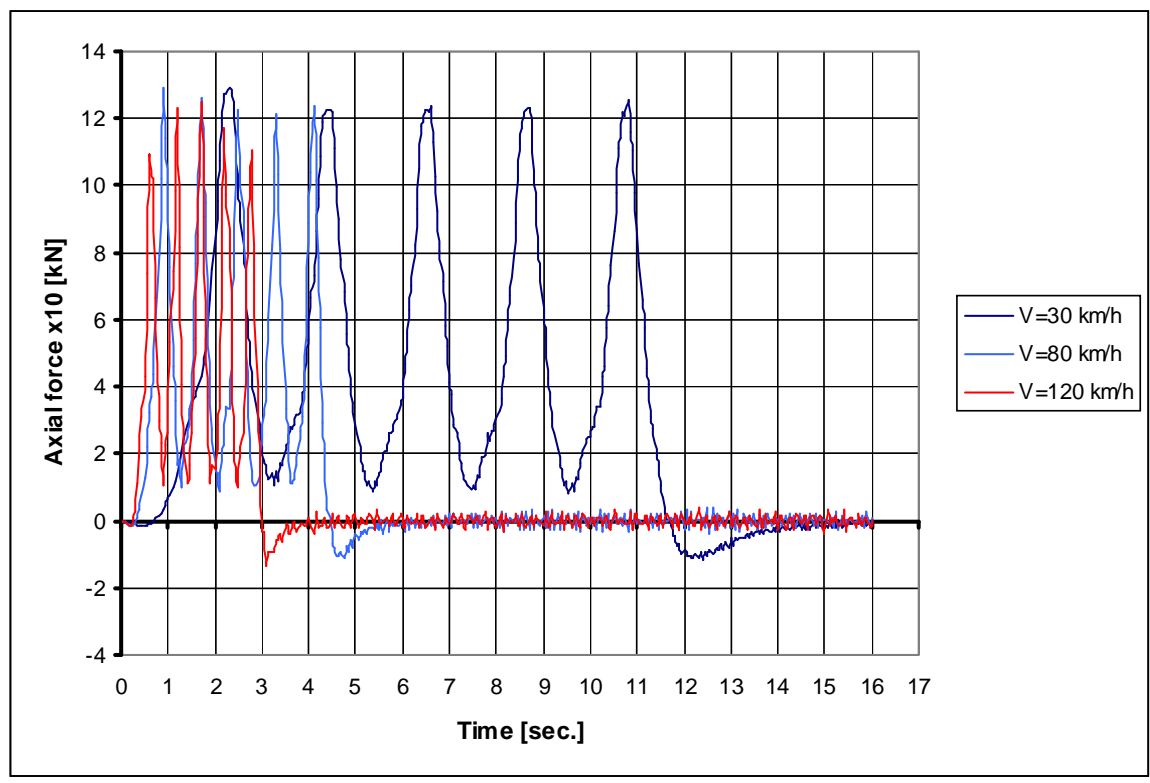

Figure 6. Time-history for the axial force in the hanger 10

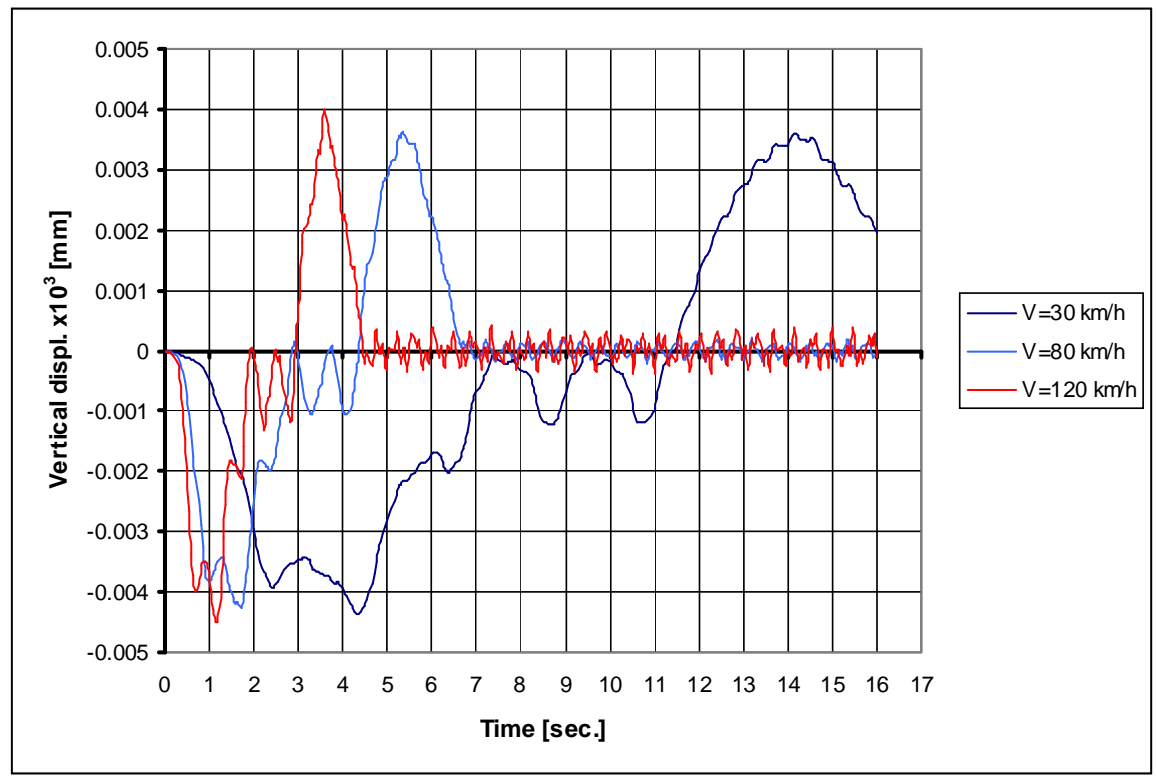

Figure 7. Time-history for the vertical displacement at the end of hanger 10

From figures above it can be observed that the axial force in the hanger change sign and has a strong variation due to the vibrations induced by the action of the vehicle. The same tendency can be remarked also for the vertical displacement of the point at the end of the hanger. These evolutions of the 
ROMANIAN JOURNAL

\section{OF TRANSPORT INFRASTRUCTURE}

Ionuţ Radu Răcănel, Marian Daraban, Răzvan Stănescu, Some investigations performed for the bridge over Jiu at Aninoasa

stresses and displacements can lead in time to the crack formation in the hangers concrete structure.

\section{REFERENCES}

[1]. ***, STAS 10101/OB-87, "Acţiuni în construcţii. Clasificarea şi gruparea acţiunilor pentru podurile de cale ferată şi şosea".

[2]. ***, "CSI Analysis Reference Manual for SAP2000, Etabs and Safe, Computers and Structures Inc.”, Berkeley, California, 2007.

[3]. S.C. I.P.T.A.N.A S.A., "Proiect de consolidare a podului peste Jiul de Vest la Aninoasa", 2007.

[4]. S.C. I.P.T.A.N.A S.A., S.C. INCERTRANS S.A., "Proiect de incercare a podului peste Jiul de Vest la Aninoasa”, 2007. 